\title{
ОЦІНКА ВПЛИВУ ЗМІНИ ПАРАМЕТРІВ ФУНКЦІЇ ПЕРЕВАГИ НА РОЗПОДІЛ ПОПИТУ НА ПЕРЕМЩЩЕННЯ МІЖ ТРАНСПОРТНИМИ РАЙОНАМИ МІСТА
}

\begin{abstract}
Метою виконання роботи була оцінка того, як впливатиме зміна значень коефіцієнтів функції переваги Box-Cox, що застосовується при виконанні етапу розподілу попиту 4-етапної моделі транспортного планування в програмному середовищі Visum, на результати розподілу матриці кореспонденцій.

У PTV Visum оцифровано територію проходження тролейбусного маршруту № 29 у м. Львові та занесено необхідну початкову інформацію про режим роботи маршруту. Для отримання даних про величину пасажиропотоку на маршруті для формування початкової матриці кореспонденцій проведено натурні спостереження.

В процесі виконання першого етапу розрахунку, етапу генерації попиту, розраховано ступені генерації та притягання для кожного транспортного району на шляху руху маршруту. На етапі розподілу попиту початкову матрицю кореспонденцій розподілено між шарами попиту в залежності від мети переміщення (всього отримано 7 таких матриць). Коефіцієнти використовуваної функції переваги Вох-Сох розраховувалися на основі параметрів сформованої еліпсової моделі території проектування.

Щоб проаналізувати вплив значень коефіцієнтів функції переваги на значення отриманих матриць, почергово змінювалися значення коефіцієнтів та проводився перерахунок етапу розподілу попиту у PTV Visum. Зміна значень коефіцієнтів не здійснює впливу на сумарну величину матриці, проте змінює суму прибуттів в кожен транспортний район. Визначено граничні значення коефіцієнтів функції Вох-Сох, при перевищенні яких розподіл між транспортними районами суттєво змінюється. Чим більші абсолютні значення коефіцієнтів досліджуваної функції переваги, тим більше впливу на кінцевий результат матриць матиме похибка в їх розрахунку.

Ключові слова: транспортне моделювання, 4-етапна модель транспортного попиту, розподіл попиту, функція переваги, PTV Visum
\end{abstract}

\section{ВСТУП}

Рішення, які приймаються в сфері транспортного планування та організації роботи транспорту, мають бути виваженими, оскільки вони здійснюють вплив на міську транспортну систему та іiі користувачів, а також загалом на якість міського середовища. Використання спеціалізованих програмних продуктів дозволяє моделювати транспортні процеси, прогнозуючи можливі результати впровадження певних заходів.

Програмне середовище PTV Visum на сьогодні є одним 3 найефективніших пакетів для моделювання транспортних систем міст [1]. При моделюванні з його допомогою розподілу пасажирських кореспонденцій зазвичай використовується чотирьохетапна модель транспортного попиту $[2,3]$. На першому етапі проводиться визначення кількості поїздок, які генеруються i притягуються кожним транспортним районом, на етапі розподілу транспортного попиту формування матриць кореспонденцій для кожного шару попиту, на етапі вибору режиму - розподіл транспортних кореспонденцій за видами транспорту, i на четвертому етапі - перерозподіл переміщень по вуличній та маршрутній мережі.

На етапі розподілу попиту необхідне застосування функції переваги для моделювання розподілу переміщень між транспортними районами. Визначення коефіцієнтів функції переваги проводиться окремо для кожної території моделювання на основі аналізу проведених натурних обстежень, анкетних опитувань тощо. Похибки в розрахунках значень цих коефіцієнтів вплинуть на якість транспортної моделі та достовірність їі результатів. Тому оцінка впливу їх зміни на загальний результат моделювання $\epsilon$ актуальною задачею.

\section{АНАЛІЗ ЛІТЕРАТУРНИХ ДАНИХ ТА ПОСТАНОВКА ПРОБЛЕМИ}

Моделювання процесу формування транспортних та пасажирських потоків відбувається за спільним для всіх методів принципом: користувачі транспортної системи мають набір альтернатив для пересування (режими руху, шляхи переміщення тощо). Кожна 3 цих альтернатив має свої характеристики, і користувач здійснює вибір між ними, шукаючи варіант, який якомога більше задовольнятиме його вимогам [4].

Чинники, які здійснюють вплив на вибір пасажирами шляху їх пересування, поділяються на чотири групи: чинники, що характеризують витрати часу на переміщення, чинники, які оцінюють 
зручність переміщення, чинники, що характеризують фінансові витрати пасажирів та чинники соціоекономічних характеристик населення [5].

Якщо користувач обирає режим свого переміщення (громадський транспорт, приватний транспорт, велорух тощо), то при здійсненні вибору враховуються такі групи чинників, як характеристики користувача (вік, стать, рівень доходу, наявність власного автомобіля), показники переміщення (мета, відстань, напрям, пункти генерації та притягання) та параметри транспортної системи (середній час очікування, експлуатаційна швидкість, комфорт) [6, 7].

Витрати часу на переміщення $є$ одним з основних чинників, який впливає на вибір пасажирами способу свого пересування. Проте це не єдиний чинник. Зокрема, в праці [8], можливі альтернативи шляхів оцінюються, окрім часу на пересування, величиною тарифу на поїздку та показником транспортної стомлюваності пасажира. Вплив цих чинників на вибір користувача залежить від його середнього доходу та відстані поїздки.

В роботі [9] авторка пропонує враховувати при виборі способу пересування такі основні характеристики переміщення, як час та вартість.

Горбачов П.Ф. у своїй праці розраховує ймовірність вибору шляху пересування при виконанні трудових переміщень на основі тривалості переміщення, коефіцієнта заповнення салону автобуса, вартості поїздки та кількості пересадок [10].

Автори [11] при розрахунку ймовірності вибору пасажирами маршруту пересування враховували час очікування пасажиром транспортного засобу на зупинці. На основі даних, отриманих під час анкетування пасажирів в місті Кременчук, ними отримана функція переваги, коефіцієнти якої визначалися методом підбору.

В роботі [12] привабливість шляху переміщення маршрутним транспортом визначається 3 врахуванням вартості поїздки, інтервалів руху, ймовірності відмови в посадці, заповнення салону ТЗ, витрат часу на підхід до зупинки та наявності пересадок. Важливість цих чинників визначалася шляхом аналізу анкет опитування в м. Рівне.

На основі проведеного аналізу літературних джерел можна зробити висновок, що при оцінці ймовірності виконання переміщення певним режимом руху базовим показником є час пересування. Вибір функції ймовірності та підбір значень їх коефіцієнтів проводиться окремо в кожному конкретному випадку залежно від виду території проектування.

\section{ЦІЛЬ ТА ЗАДАЧІ ДОСЛІДЖЕННЯ}

Ціллю проведеного дослідження є оцінка впливу коефіцієнтів функції переваги ВохСох на зміну розподілу величини попиту на переміщення між транспортними районами міста. Для виконання поставленої мети виконано такі задачі:

- територію дослідження змодельовано в програмному середовищі Visum;

- розраховано матрицю кореспонденцій між транспортними районами;

- розраховано значення коефіцієнтів функції переваги ВохСох для етапу розподілу переміщень між шарами попиту;

- 3 допомогою моделювання у Visum проаналізовано вплив зміни значень коефіцієнтів функції на загальну величину кореспонденцій та їх перерозподіл між транспортними районами.

\section{РЕЗУЛЬТАТИ ДОСЛІДЖЕНЬ}

Основою для проведення розподілу транспортного попиту є матриці кореспонденцій, для отримання яких необхідно розв'язати задачу максимізації функції для кожного шару попиту [13]:

$$
\sum_{i, j=1}^{n} F_{i j} \ln \left(\frac{P_{i j}}{F_{i j}}\right) \rightarrow \max
$$

При таких обмеженнях:

$$
\begin{gathered}
\sum_{j=1}^{n} F_{i j}=Q_{i} \\
\sum_{i=1}^{n} F_{i j}=Z_{i}
\end{gathered}
$$



район $j$ :

В результаті розв'язання задачі оптимізації отримується величина кореспонденцій з району $i$ в

$$
F_{i j}=k \cdot Q_{i} \cdot Z_{j} \cdot P_{i j}\left(U_{i j}\right)=k \cdot Q_{i} \cdot Z_{j} \cdot e^{\frac{c\left(U_{i j}^{b}-1\right)}{b}}
$$

Де $P_{i j}\left(U_{i j}\right)$ - функція переваги, що характеризує ставлення учасника руху до витрат на переміщення.

В транспортних моделях міст часто застосовують функцію переваги Вох-Сох, названу в честь учених Джорджа Бокса та Девіда Кокса, яка має вигляд [2]:

$$
f\left(U_{i j}\right)=e^{\left(c \cdot \frac{U_{i j}^{b}-1}{b}\right)}
$$

Де $U_{i j}$ - витрати на виконання кореспонденції між кожною парою транспортних районів;

$b, c$ - коефіцієнти функції.

По осі абсцис відкладається час на здійснення переміщення, а по осі ординат - ймовірність здійснення такого переміщення.

Одним зі способів визначення коефіцієнтів функції переваги Вох-Сох є застосування еліпсової моделі території. Ця модель відображає просторовий розподіл місць проживання населення, i, відповідно, характеризує генеруючу здатність окремих будівель і транспортних районів загалом [13].

Суть розрахунку полягає в тому, що спершу висувається припущення про те, що розподіл житлових будівель територією міста підпорядковується нормальному закону розподілу. Потім розраховуються математичні відхилення розподілу просторових координат житлових будівель, стандартні відхилення $\sigma_{x}, \sigma_{y}$ та коефіцієнт кореляції $\rho$. Далі обирається такий переріз, при якому 90\% всіх житлових будинків досліджуваної області попадуть у внутрішню область еліпса. Функція ймовірності для геометричного місця точок матиме вигляд:

$$
\begin{aligned}
& P(x, y)=1-e^{\lambda / 2} \\
& 1-e^{\lambda / 2}=0,9
\end{aligned}
$$

При такій умові значення щільності ймовірності становитиме $\lambda=4,61$.

Довжини півосей еліпса ( $a_{e л}$ - мала піввісь еліпса, $b_{e л}$ - велика піввісь еліпса) визначаються за такими формулами:

$$
\begin{aligned}
& a_{e \lambda}=\sigma_{y} \sqrt{2 \lambda\left(1-\rho^{2}\right)} \\
& b_{e n}=\sigma_{x} \sqrt{2 \lambda\left(1-\rho^{2}\right)}
\end{aligned}
$$

Зв'язок між параметрами еліпса та коефіцієнтами функції Вох-Сох описується виразами:

$$
\begin{gathered}
b=k_{1}\left(a_{e n}+b_{e n}\right) \\
c=k_{2} \frac{a_{e n}}{b_{e n}}
\end{gathered}
$$

Де $k_{1}, k_{2}$ - коефіцієнти пропорційності.

Для проведення розрахунків у програмному середовищі Visum створено детальну (з точністю до окремої будівлі) модель території проходження міського тролейбусного маршруту № 29 Львова та внесено всі показники роботи маршруту (розклад руху, тривалості простою на зупинках тощо). Територію руху маршруту поділено на 15 транспортних районів. Кількість районів рівна кількості зупинок на маршруті в одному напрямку. Кількість жителів в будинку визначалася як добуток 
кількості поверхів, під’їздів, квартир та жителів в квартирі. При розрахунку приймалося, що в кожному під їзді є по 4 квартири, а в квартирі проживає 3 жителі. Згідно статистичних даних по місту Львову [14], станом на 2019 рік у Львові проживає 30,9\% непрацюючого населення (діти до 14 років і пенсіонери), $21 \%$ студентів та 48,1\% працюючого населення. 3 врахуванням цих даних розраховано середню кількість жителів кожної з груп населення в транспортних районах.

Для визначення пасажиропотоків на досліджуваному маршруті проводилися натурні дослідження протягом робочих днів тижня.

Результати розрахунків параметрів еліпсової моделі подано в табл. 1.

Таблиця 1. Результати розрахунків параметрів розподілу житлових будівель на території проектування з врахуванням кількості жителів

\begin{tabular}{|l|c|}
\hline \multicolumn{1}{|c|}{ Показник } & Значення \\
\hline Середнє математичне очікування $M X$ & 313250 \\
\hline Середнє математичне очікування $M Y$ & 221652 \\
\hline Стандартне відхилення $\sigma_{x}$ & 311995 \\
\hline Стандартне відхилення $\sigma_{y}$ & 220756 \\
\hline Коефіцієнт кореляції $\rho$ & 0.99226 \\
\hline
\end{tabular}

Значення коефіцієнтів пропорційності взято з рекомендацій авторів [15].

Згідно з формулами (6 - 8):

$a_{e r}=220756,2 \cdot \sqrt{2 \cdot 4,61 \cdot\left(1-0,992259^{2}\right)}=83244,84 \mathrm{M}$

$b_{\text {eл }}=311995 \cdot \sqrt{2 \cdot 4,61 \cdot\left(1-0,992259^{2}\right)}=117650,02 \mathrm{M}$

$b=0,000006429 \cdot(83244,84+117650,02)=1,291553072$

$c=-0,00615094 \cdot \frac{83244,84}{117650,02}=-0,00435218$

Функція Вох-Сох набуде вигляду:

$$
f\left(U_{i j}\right)=e^{\left(-0,00435218 \cdot \frac{U_{i j}^{b}-1}{1,291553072}\right)}
$$

На рис. 1 подано графік отриманої функції.

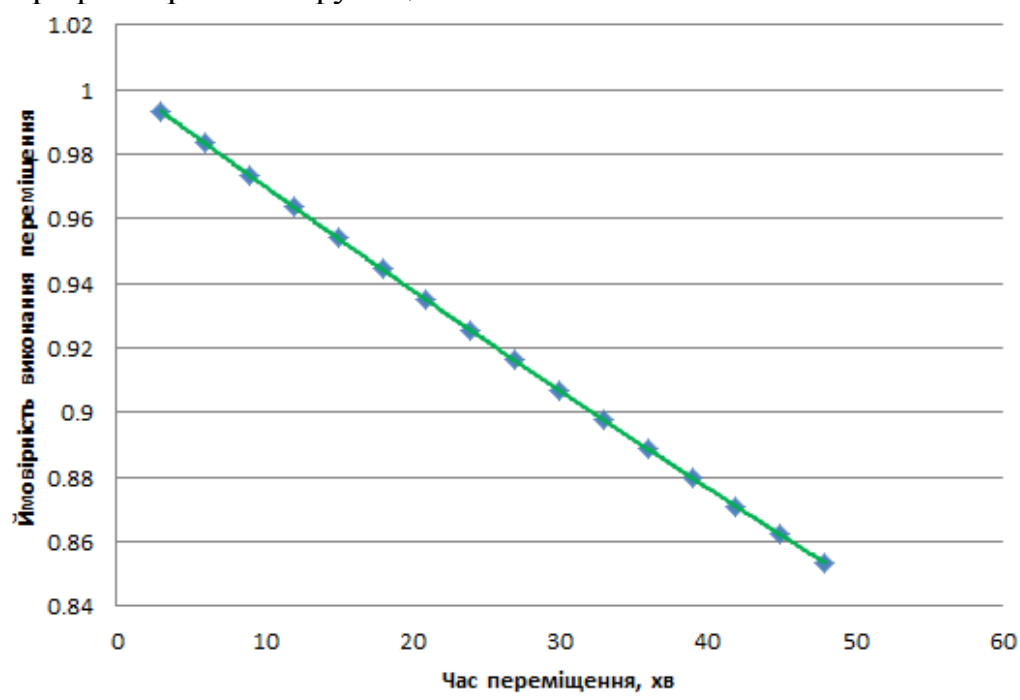

Рис. 1. Графік функції Вох-Сох, отриманий в результаті розрахунку показників еліпсової моделі території 
При проведенні процедури розподілу руху пасажиропотоки розподілялися по семи шарах попиту: дім - робота, дім - навчання, дім - інше, робота - дім, навчання - дім, інше - дім та інше інше. В результаті отримано 7 матриць кореспонденцій. Розподіл проводився на основі функції переваги Вох-Сox з вище розрахованими параметрами та матриці затрат часу на переміщення при користуванні досліджуваним маршрутом.

На основі результатів проведеного у Visum моделювання здійснено аналіз впливу на результати процедури розподілу переміщень значень коефіцієнтів функції переваги ВохСох. Очевидно, що зміна значень коефіцієнтів функції переваги не змінює сумарну величину матриці попиту, а тільки змінює розподіл кореспонденцій між районами.

Якщо значення коефіцієнта $b$ залишати незмінним, а змінювати тільки значення коефіцієнта $c$, то величина відправок з транспортних районів залишатиметься незмінною, а кількість прибуттів змінюватиметься.

Аналогічно, при однаковому значенні коефіцієнта $c$ зміна коефіцієнта $b$ не змінює суму відправок транспортних районів, але змінює суму прибуттів. Також зміна коефіцієнта $b$ змінює не тільки сумарні значення кореспонденцій, але й розподіл їх між районами. Для прикладу на рис. 2 подано матриці кореспонденцій для шару попиту дім - інше при значенні $b=2$ та $b=8$.

a)

\begin{tabular}{|c|c|c|c|c|c|c|c|c|c|c|c|c|c|c|c|c|}
\hline ne & & 1 & 2 & 3 & 4 & & 6 & 7 & 8 & $y$ & 10 & 11 & 12 & 13 & 14 & 15 \\
\hline & Sum & 133.17 & 0.00 & 225.28 & 135.50 & 2721.19 & 0.00 & 114.08 & 68.48 & 1824.53 & 0.00 & 68.19 & 0.00 & 180.67 & 0.00 & 223494 \\
\hline 1 & $289.5 \%$ & 5.34 & 0.00 & 8.86 & 5.30 & 104.45 & 0.00 & 4.35 & 259 & 68.53 & 0.00 & 253 & 0.00 & 6.63 & 0.00 & 80.98 \\
\hline 2 & 164.10 & 3.00 & 0.00 & 4.99 & 299 & 59.05 & 0.00 & 246 & 1.47 & 38.83 & 0.00 & 1.44 & 0.00 & 3.77 & 0.00 & 46.12 \\
\hline 3 & 386.12 & 6.91 & 0.00 & 11.65 & 6.98 & 138.50 & 0.00 & 5.77 & 3.44 & 91.33 & 0.00 & 3.39 & 0.00 & 8.91 & 0.00 & 109.23 \\
\hline 4 & $\$ 15.08$ & 7.41 & 0.00 & 1243 & 7.47 & 148.54 & 0.00 & 6.19 & 3.70 & 98.14 & 0.00 & 3.65 & 0.00 & 9.60 & 0.00 & 117.94 \\
\hline 5 & 304.98 & 10.72 & 0.00 & 18.00 & 10.81 & 216.55 & 0.00 & 8.99 & 5.38 & 14283 & 0.00 & 5.31 & 0.00 & 14.01 & 0.00 & 17230 \\
\hline 6 & 359.8: & 9.84 & 0.00 & 16.57 & 9.96 & 199.65 & 0.00 & 8.31 & 4.98 & 13230 & 0.00 & 4.93 & 0.00 & 13.01 & 0.00 & 160.33 \\
\hline 7 & 317.03 & 15.92 & 0.00 & 26.91 & 16.18 & 325.32 & 0.00 & 13.62 & 8.16 & 217.10 & 0.00 & 8.10 & 0.00 & 21.41 & 0.00 & 264.31 \\
\hline 8 & 265.46 & 4.57 & 0.00 & 7.74 & 4.65 & 93.65 & 0.00 & 3.93 & 236 & 6284 & 0.00 & 235 & 0.00 & 6.23 & 0.00 & 7.14 \\
\hline 9 & 044.4 & 17.83 & 0.00 & 30.25 & 18.21 & 366.92 & 0.00 & 15.42 & 9.27 & 247.42 & 0.00 & 927 & 0.00 & 24.61 & 0.00 & 30520 \\
\hline 10 & 1932 & 20.23 & 0.00 & 34.40 & 20.71 & 417.80 & 0.00 & 17.59 & 10.59 & 28277 & 0.00 & 10.61 & 0.00 & 2820 & 0.00 & 350,32 \\
\hline 11 & 1784 & 19.87 & 0.00 & 33.83 & 20.38 & 411.41 & 0.00 & 17.35 & 10.45 & 279.32 & 0.00 & 10.49 & 0.0 & 27.93 & 0.00 & 347.44 \\
\hline 12 & 534.15 & 10.63 & 0.00 & 18.12 & 10.92 & 220.72 & 0.00 & 9.32 & 5.62 & 150.37 & 0.00 & 5.65 & 0.00 & 15.07 & 0.00 & 187.73 \\
\hline 13 & 53.63 & 0.89 & 0.00 & 1.53 & 0.92 & 18.62 & 0.00 & 0.79 & 0.48 & 12.74 & 0.00 & 0.48 & 0.0 & 1.28 & 0.00 & 15.90 \\
\hline 14 & 0.00 & 0.00 & 0.00 & 0.00 & 0.00 & 0.00 & 0.00 & 0.00 & 0.00 & 0.00 & 0.00 & 0.00 & 0.00 & 0.00 & 0.00 & 0.00 \\
\hline 15 & 0.00 & 0.00 & 0.00 & 0.00 & 0.00 & 0.00 & 0.00 & 0.00 & 0.00 & 0.00 & 0.00 & 0.00 & 0.0 & 0.00 & 0.0 & 0.00 \\
\hline Name & & 1 & 2 & 3 & 4 & 5 & 6 & 7 & 8 & 9 & 10 & 11 & 12 & 13 & 14 & 15 \\
\hline & Sum & 14547 & 0.00 & 301.1 & 185.53 & 2499.46 & 0.00 & 71.83 & 100.16 & 2445.19 & 0.00 & 77.59 & 0.00 & 169.06 & 0.00 & 1610.56 \\
\hline 1 & 289.56 & 79.77 & 0.00 & 131.88 & 74.90 & 295 & 0.00 & 0.10 & 0.00 & 0.00 & 0.00 & 0.00 & 0.00 & 0.00 & 0.00 & 0.00 \\
\hline 2 & 164.10 & 21.44 & 0.00 & 35 & 21 & 8243 & oc & 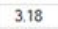 & 0.01 & & 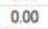 & 0.0 & 0.0 & 0.00 & 0.0 & 0.00 \\
\hline 3 & 386.12 & 12.23 & 0.00 & 30.26 & 18.16 & 305.55 & 0.00 & 12.60 & 3.16 & 4.16 & 0.00 & 0.00 & 0.0 & 0.00 & 0.00 & 0.00 \\
\hline 4 & 415.05 & 13.52 & 0.00 & 24.07 & 14.44 & 28225 & 0.00 & 11.74 & 5.78 & 63.28 & 0.00 & 0.00 & 0.00 & 0.00 & 0.00 & 0.00 \\
\hline 5 & 304.92 & 13.93 & 0.00 & 29.29 & 17.58 & 351.70 & oc & 14 & 8. & 169.00 & 制 & 0.43 & 0 & 0. & 0.0 & 0.00 \\
\hline 6 & $559.8 ?$ & 4.59 & 0.00 & 24.7 & 15.0 & 301.68 & 0. & 12 & 7 & 190. & & 3.35 & 0.0 & 0.01 & 0.00 & 0.00 \\
\hline 7 & 9170 : & 0.00 & 0.00 & 2273 & 19.47 & 494.94 & 0.00 & 20.92 & 1255 & 33287 & 0.00 & 10.58 & 0.00 & 298 & 0.00 & 0.00 \\
\hline 8 & 265.46 & 0.00 & 0.00 & 231 & 3.38 & 136.26 & 0.00 & 6. & 3.64 & 97.18 & 000 & 3.63 & 0 & 8.08 & 0.00 & 4.89 \\
\hline 9 & 0444 & 0.00 & 0.00 & 0.12 & 1.25 & 366.72 & 0.00 & 23.33 & 14.03 & 374 & 00 & 14.03 & 0.00 & 36.58 & 0.00 & 21425 \\
\hline 10 & 1932 & 0.00 & 0.00 & 0.00 & 0.01 & 156.91 & 0.00 & 28.03 & 17.15 & 457.60 & 0.00 & 17.16 & 0.00 & 45.66 & 0.00 & 470.70 \\
\hline 11 & 1784 & 0.00 & 0.00 & 0.00 & 0.00 & 18.03 & 0.00 & 27. & 17.81 & 476 & 0.00 & 17.87 & 0.00 & 47 & 0.00 & 573.43 \\
\hline 12 & 534.16 & 0.00 & 0.00 & $0.0 x$ & 0.0 & 0.0 & 0. & & & 257 & & & 0. & 25.8 & 0.00 & 320.35 \\
\hline 13 & 53.63 & 0.00 & 0 & 0.00 & 0.00 & 00 & 0. & 0.3 & 0.7 & 22 & & 0.8 & 0.00 & 2 & 0.00 & 26.94 \\
\hline 14 & 0.00 & 0.00 & 0.00 & 0.00 & 0.00 & 0.00 & 0.00 & 0. & 0 & 0. & 0.00 & 0.00 & 0.00 & .00 & 0.00 & 0.00 \\
\hline 15 & 0.00 & 0.00 & 0.00 & 0.00 & 0.00 & 0.00 & 0.00 & 0.00 & 0.00 & 0.00 & 0.00 & 0.00 & 0.00 & 0.00 & 0.00 & 0.00 \\
\hline
\end{tabular}

Рис. 2. Матриця кореспонденцій для шару попиту дім - інше: а) при значенні коефіцієнта $b=2$; при значенні коефіцієнта $b=8$

За зміною значень матриць можна простежити, що при збільшенні значення коефіцієнта $b$ всі кореспонденції починають тяжіти до шляхів 3 меншими затратами часу на переміщення і для сполучень між віддаленими транспортними районами кореспонденції стають нульовими (a, отже, реалістичність результатів розподілу стає сумнівною).

\section{ОБГОВОРЕННЯ РЕЗУЛЬТАТІВ ДОСЛІДЖЕНЬ}

Для того, щоб оцінити величину зміни значень, проведено розрахунки абсолютних, відносних відхилень та коефіцієнтів варіації [16].

При значенні коефіцієнта функції Вох-Сох $c \geq-0,1$ коливання результатів $\epsilon$ порівняно незначними. Відносні відхилення в цьому випадку не перевищують $15 \%$, а середнє їх значення знаходиться в межах 7\%. При зменшенні величини коефіцієнта $c$ відхилення починають зростати, $\mathrm{i}$ при значеннях $-0,5 \geq c \leq-0,1$ середні відхилення знаходяться в межах $24 \%$. При збільшенні значення коефіцієнта $c$ середні відносні відхилення зменшуються за прямолінійною залежністю (рис. 3): 


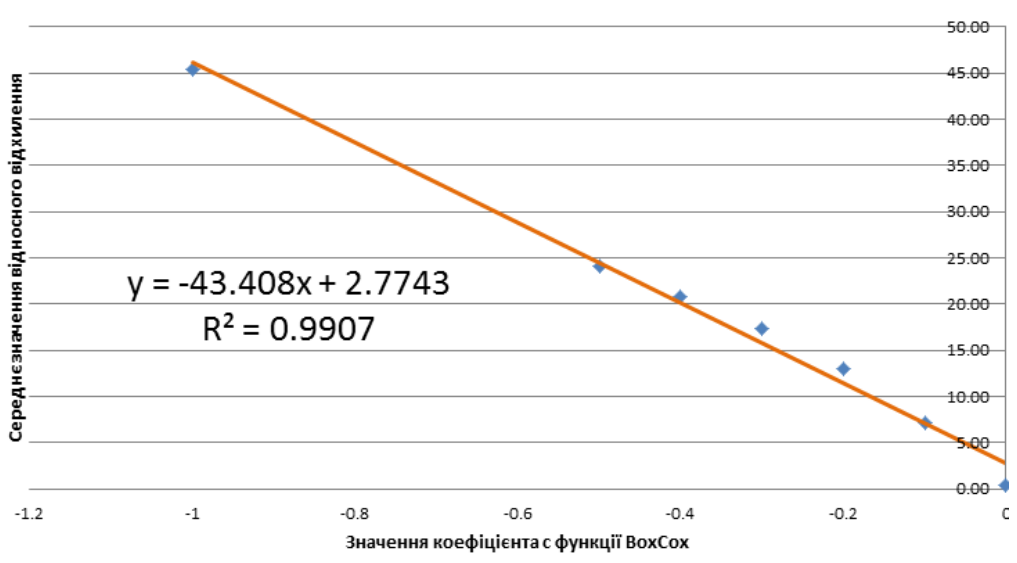

Рис. 3. Тенденція зміни середніх значень відносних відхилень величини кореспонденцій залежно від зміни значень коефіцієнта $c$

Щодо впливу зміни значень коефіцієнта $b$ на розподіл кореспонденцій між транспортними районами можна зробити такі висновки:

- при значенні коефіцієнта $b \leq 2$ його зміна несуттєво впливає на величину розподілу кореспонденцій (середня відносна похибка становить $0,37 \%$, максимальна - не перевищує $1 \%)$

- при значенні коефіцієнта $2 \geq b \leq 4$ середня відносна похибка значень матриць кореспонденцій становить 7\%, максимальне спостережуване значення - $16 \%$;

- $\quad$ при значенні коефіцієнта $b \geq 4$ похибки починають різко зростати.

Графік зміни середніх відносних відхилень коефіцієнта $b$ залежно від зміни його значення подано на рис. 4.

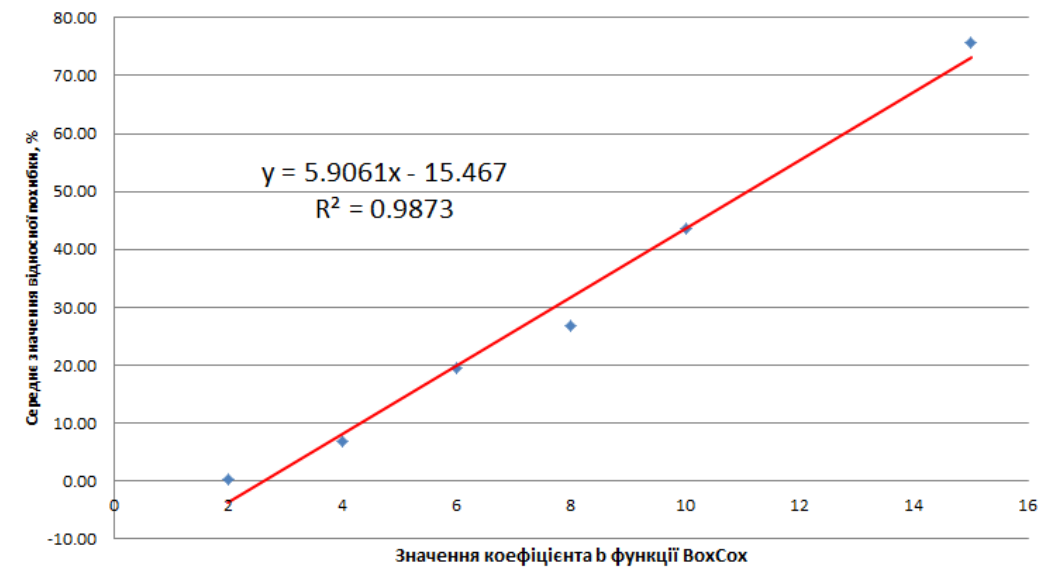

Рис. 4. Тенденція зміни середніх значень відносних відхилень величини кореспонденцій залежно від зміни значень коефіцієнта $b$

Для того, щоб оцінити наявність взаємозв'язку між значеннями відносних відхилень розподілу кореспонденцій по транспортних районах та кількістю жителів і кількістю місць культурнопобутового призначення в районі, проведено регресійний аналіз. Проте результати аналізу не не показали достатнього зв'язку між цими показниками: коефіцієнт кореляції Пірсона в жодному 3 випадків не перевищив значення 0,6 (точність регресійної моделі достатня при значенні $R>0.7$ ), а коефіцієнт детермінації $R^{2}$ - значення 0,36 (точність регресійної моделі достатня при значенні коефіцієнта детермінації $R^{2}>0.5$ ).

\section{ВИСНОВКИ}

Щоб оцінити вплив значень параметрів функції переваги Вох-Сох на значення матриць кореспонденцій, отриманих в результаті розподілу попиту на переміщення громадським транспортом y Visum, проводився перерахунок етапу при різних значеннях коефіцієнтів $b$ та $c$. Зміна значень коефіцієнтів не здійснює впливу на сумарну величину матриці кореспонденцій та не змінює сумарні 
значення рядків матриці (кількість відправок), проте змінює сумарні значення стовпців матриці (кількість прибуттів). Визначено, що якщо значення коефіцієнта $c$ знаходяться в межах від -1 до 0 , то його зміна несуттєво вплине на розподіл кількості переміщень між районами. Якщо ж значення $c<-1$, то похибка в його розрахунку вплине на достовірність отриманого результату. Незначний вплив на результати розрахунку кореспонденцій спостерігався при значенні коефіцієнта $b$ менше 4 . При подальшому зростанні $b$ похибки результатів розрахунку матриць стають значними, а кореспонденції починають прив'язуватися тільки до шляхів з меншою тривалістю поїздки, що не відповідає реальним умовам розподілу переміщень.

Отримані результати допоможуть дослідникам оцінити необхідну величину вибірки при визначенні значень коефіцієнтів функції переваги Вох-Сох для етапу розподілу попиту на основі проведення анкетувань чи натурних досліджень. Якщо при мінімальній величині вибірки отримані коефіцієнти знаходяться в межах $c>-1$ чи $b<4$, то результати можна застосовувати для моделювання, якщо ж значення коефіцієнтів є вищими, то доцільно провести додаткові дослідження, щоб неточність в їх розрахунку не вплинула негативно на результат моделювання.

\section{ПЕРЕЛІК ДЖЕРЕЛ ПОСИЛАННЯ}

1. Любий С.В. Транспортне планування міст: сучасні інструменти транспортного моделювання автотранспортних систем / С.В. Любий, Н.В. Пономарьова, О.С. Чернишова // Комунальне господарство міст. - Харків, 2016. - Випуск 128. с. 76-82.

2. VISUM 11.5. Basics. Karlsruhe, 2010. 756 p.

3. Willumsen G., Ortuzar D. Modelling Transport. 3rd Edition, London, 2006. - 300 p.

4. Брайловский Н.О., Грановский Б.И. Моделирование транспортных систем. М.: Транспорт, 1978. $-125 \mathrm{c}$.

5. Cascetta, E. Transportation Systems Analysis. Springer Optimization and Its Applications. - Springer US, 2009. - $742 \mathrm{p}$.

6. Бонсалл П.У., Чемпертоун А.Ф., Мейсон А.К., Уилсон А.Г. Моделирование пассажиропотоков в транспортной системе. Пер. с англ. М.: Транспорт, 1982. - 207 с.

7. Доля В.К. Пасажирські перевезення: підручник. Х.:Форт, 2011. - 504 с.

8. Понкратов Д.П. Вибір пасажирами шляху пересування у містах: монографія / Д.П. Понкратов, Г.І. Фалецька - Х.: ХНУМГ ім. О.М. Бекетова, 2015. - 164 с.

9. Свічинська О.В. Удосконалення моделей вибору шляху пересування пасажирів в маршрутних системах міст: автореф. дис. канд. техн. наук спеціальності 05.22.01. Харків, 2015. - 23 с.

10. Горбачов, П. Ф. Концепція формування систем маршрутного пасажирського транспорту в містах: автореф. дис. докт. техн. наук: спец. 05.22.01. Харків, 2009. - 39 с.

11. Хорольський В.Р. Дослідження закономірностей вибору пасажирами альтернативних маршрутів сполучення / В.Р. Хорольський, В.В. Богаєнко, В.О. Шерметов // Сучасні технології в машинобудуванні, транспорті та гірництві. Вісник КрНУ ім. М.Остроградського. - 2016. - Вип. 5, ч.2. с. $71-76$.

12. Кристопчук М.Є. Дослідження факторів впливу на розподіл пасажирських кореспонденцій по маршрутній мережі. «Наукові нотатки». - 2014. - Випуск № 45. Луцьк. с. 317 - 322.

13. Якимов М.Р. Транспортное планирование: создание транспортных моделей городов: монография. - Москва, 2013. - 188 с.

14. Головне управління статистики у Львівській області. URL: http://www.lv.ukrstat.gov.ua/ukr/themes/19/theme_19.php?code=19.

15. Трофименко Ю.В. Транспортное планирование: формирование эффективных транспортных систем крупных городов: монографія / Ю.В. Трофименко, М.Р. Якимов - М.: Логос, 2013. - 464 c.

16. Клименко Л.П. Метрологія, стандартизація та управління якістю / Л.П. Клименко, Л.В. Пізінцалі, Н.І. Александровська, В.Д. Євдокимов - Миколаїв: Вид-во ЧДУ ім. Петра Могили, 2011. - 243 с.

\section{REFERENCES}

1. Liubyi, Ye.V., Ponomarova, N.V., Chernyshova O.S. (2016). Transportne planuvannia mist: suchasni instrumenty transportnoho modeliuvannia avtotransportnykh system. Komunalne hospodarstvo mist. $128,76-82$.

2. VISUM 11.5. Basics. Karlsruhe, 2010. 756 p.

3. Willumsen G., Ortuzar D. (2006). Modelling Transport. 3rd Edition, 300. 
4. Brailovskyi, N.O., Hranovskyi, B.Y. (1978). Modelyrovanye transportnykh system, 125.

5. Cascetta, E. (2009). Transportation Systems Analysis, 742.

6. Bonsall P.U., Chempertoun A.F., Meison A.K., Uylson A.H. (1982). Modelyrovanye passazhyropotokov v transportnoi systeme. Transport. 207.

7. Dolia, V.K. (2011). Pasazhyrski perevezennia: pidruchnyk, 504.

8. Ponkratov, D.P., Faletska, H.I. (2015). Vybir pasazhyramy shliakhu peresuvannia u mistakh: monohrafiia. 164.

9. Svichynska, O.V. (2015). Udoskonalennia modelei vyboru shliakhu peresuvannia pasazhyriv v marshrutnykh systemakh mist: avtoref. dys. kand. tekhn. nauk spetsialnosti 05.22.01. Kharkiv. 23.

10. Horbachov, P. F. (2009). Kontseptsiia formuvannia system marshrutnoho pasazhyrskoho transportu v mistakh: avtoref. dys. dokt. tekhn. nauk: spets. 05.22.01. Kharkiv. 39.

11. Khorolskyi, V.R., Bohaienko, V.V., Shermetov, V.O. (2016). Doslidzhennia zakonomirnostei vyboru pasazhyramy alternatyvnykh marshrutiv spoluchennia. Suchasni tekhnolohii v mashynobuduvanni, transporti ta hirnytstvi. Visnyk KrNU im. M.Ostrohradskoho. 5(2), $71-76$.

12. Krystopchuk, M.Ie. (2014). Doslidzhennia faktoriv vplyvu na rozpodil pasazhyrskykh korespondentsii po marshrutnii merezhi. «Naukovi notatky». 45, 317-322.

13. Iakymov, M.R. (2013). Transportnoe planyrovanye: sozdanye transportnykh modelei horodov: monohrafyia, 188 .

14. Holovne upravlinnia statystyky u Lvivskii oblasti. URL: http://www.lv.ukrstat.gov.ua/ukr/themes/19/theme 19.php?code=19.

15. Trofymenko, Yu.V., Yakymov, M.R. (2013). Transportnoe planyrovanye: formyrovanye effektyvnykh transportnykh system krupnykh horodov: monohrafiia, 464.

16. Klymenko, L.P., Pizintsali, L.V., Aleksandrovska, N.I., Yevdokymov, V.D. (2011). Metrolohiia, standartyzatsiia ta upravlinnia yakistiu, 243.

\section{H. Pivtorak, V. Holomovzyy, M. Zhyla. Assessment of the influence of changes in the parameters of} the utility function on the trip distribution between the transport zones of the city.

The purpose of this work was to determine the coefficients of the utility function of Box-Cox in the distribution in the Visum software demand for public transport in Lviv and assess the impact of their change on the results of the trip distribution.

The trolleybus route № 29 of Lviv was chosen for the simulation. The territory of its passage was digitized in Visum, the necessary initial information about the route was entered, as well as field research was carried out in order to determine the size of passenger flows and the formation of the initial matrix of correspondence.

At the stage of trip generation, when calculating the four-stage model of transport planning, the total number of trips produced and attracted by each transport zone on the route is determined. At the stage of trip distribution, the received correspondence is distributed between the activity pairs (depending on the purpose of the trip). As a result, seven demand matrices were obtained. The coefficients of the Box-Cox utility functions were determined based on the results of constructing an elliptical model of the survey territory.

To analyze the influence of the values of the coefficients of the utility function Box-Cox on the values of the resulting matrices in Visum recalculated the stage of trip distribution at different values of the coefficients. The change in the coefficients does not affect the total amount of trips but affects the number of arrivals in each transport zone. The limit values of each of the coefficients are calculated, at the excess of which the error in their definition significantly affects the values of the elements of the matrix

Based on the calculations, it can be concluded that at insignificant values of the coefficients of the utility function Box-Cox inaccuracy of their definition is permissible, but with increasing absolute values, the error in their calculation significantly affects the final result. Visum

Key words: transport modeling, four-stage demand model, trip distribution, utility function, PTV

ПІВТОРАК Галина Василівна, старший викладач кафедри транспортних технологій, Національний університет «Львівська політехніка», e-mail: halyna.v.pivtorak@lpnu.ua. https://orcid.org/0000-0003-3645-1586

ГОЛОМОВЗИЙ Віктор Миколайович, кандидат економічних наук, доцент кафедри менеджменту та міжнародного підприємництва, Національний університет «Львівська політехніка», e-mail: viktor.m.holomovzyi@1pnu.ua. 
ЖИЛА Мар'яна Павлівна, студентка кафедри транспортних технологій, Національний університет «Львівська політехніка», e-mail: mariana.zhyla@gmail.com

Halyna PIVTORAK, lecturer of department of transport technologies, Lviv National Polytechnic University, e-mail: halyna.v.pivtorak@1pnu.ua. https://orcid.org/0000-0003-3645-1586

Viktor HOLOMOVZYY, PhD (Economics), Associate Professor, Department of Management and International Business, Lviv National Polytechnic University, e-mail: viktor.m.holomovzyi@1pnu.ua.

Mariana ZHYLA, student of department of transport technologies, Lviv National Polytechnic University, e-mail: mariana.zhyla@gmail.com

DOI 10.36910/automash.v2i15.399 